\title{
The Implementation of QMS, ISO 9001:2015; A Key to Improved Performance, A Case Study on Mexico Cleaning Services in Kingdom of Bahrain
}

\author{
Hassan Abduladheem Mohamed ${ }^{1}$ \\ AMA International University - Bahrain
}

\begin{abstract}
This study discusses the importance of Quality Management System implementation in Mexico Cleaning Services which is located in the Kingdom Of Bahrain in terms of six variables which are (general cleaning, provision of labor services, labor productivity, performance, employee behavior and operational cost/expense), where the Quality Management System is an important element to any successful company. The study underscores the impacts of these six variables on implementing Quality Management System in Mexico Cleaning Services, and the research shows how Mexico Cleaning Services or any other organization need to implement Quality Management system. The study demonstrated that in order to improve the overall performance, labor productivity, employee behavior and minimizing operational costs companies should implement Quality Management System. The study used the quantitative research method and the populations based were used as a main tool to collect the primary data with total of 156 respondents (150 employees and 6 top management). Finally, suggesting recommendations based on the findings of the study are presented.
\end{abstract}

Keywords: Quality management system, Labor Productivity, Performance, Employee Behavior and Operational Costs/Expenses

\section{INTRODUCTION}

Quality is considered one of the many important factors in order to be a successful organization. Most managers are focusing on costs, time and efforts instead of focusing on quality. On the other hand, researchers insist that organizations must exert more effort on taking care of improving quality. (Neyestani, 2016)

Nowadays, quality is not related only to goods and services but it is related to the process, system and management. The process should be done under a good environment and good quality. Good quality consists of some important factors, first and the most important one is the QMS as a tool of business management. (Neyestani, 2016)

Quality management and business management are closely related to each other. Business management and quality management have been always related to the concept of organization. However, business management matured with time toward managing permanent organization. This orientation reflects modern organizations that provide a superior value to its customer through the projects that the organization chose to organize its activities by starting to implement these projects. (Ingason, 2014)

This research aims to shed lights on the importance of quality management in every organization and to design quality management system in Mexico Cleaning Services in order to improve the quality of its services and to gain customers' loyalty. This study focuses on factors affecting organizations because of quality management.

The study aims to assess the role of QMS in improving the services of the company, labor productivity, performance, employee behavior and operational cost/ expenses. Mexico Cleaning Services is currently not into formal implementing a QMS. However; the company conducts simple quality measures such as onsite inspection for general cleaning services using checklists. Without the implementation of a proper QMS, the company loses some tenders in the market competition with other companies in the same field because of low level of performance and productivity and less employee commitment to the work beside high operational cost and expenses. This study aims to answer the following research questions:

1. What is the impact of implementing QMS on the internal process of MCS?

2. What is the level of efficiencies of internal processes in term of its:

a. General cleaning.

b. Provision of labor services. 


\section{International Advanced Research Journal in Science, Engineering and Technology}

Vol. 6, Issue 5, May 2019

3. Is there significant relationship between QMS implementation and the following:

a. Labor Productivity

b. Performance

c. Employee Behavior

d. Operational Costs/Expenses

\subsection{Hypothesis}

$\mathbf{H}_{\mathbf{0}}$ : There is no significant relationship between implementing QMS and Labor productivity.

$\mathbf{H}_{1:}$ There is a significant relationship between implementing QMS and Labor productivity.

$\mathbf{H}_{\mathbf{0}}$ : There is no significant relationship between implementing QMS and Performance of organization.

$\mathbf{H}_{2}$ : There is a significant relationship between implementing QMS and Performance of organization.

$\mathbf{H}_{\mathbf{0}}$ : There is no significant relationship between implementing QMS and Employee behavior.

$\mathbf{H}_{3}$ : There is a significant relationship between implementing QMS and Employee behavior.

$\mathbf{H}_{\mathbf{0}}$ : There is no significant relationship between implementing QMS and Operational cost/ expenses.

$\mathbf{H}_{4:}$ There is a significant relationship between implementing QMS and Operational cost/ expenses.

This research will be of benefit to the following:

The importance of this study will be for the following:

- Top Management: This study will help the management of MCS to understand how to evaluate and monitor quality and improve organization performance.

- To MCS Employees: The study would be beneficial in making employees tasks more useful and flexible in order to achieve organizational goals.

- To the Researcher: The study will show to researcher the benefits of implement a QMS.

- To Other Companies: This study will be beneficial to show other companies how to design a QMS in their companies.

\section{RESEARCH METHODOLOGY}

The researcher used descriptive Since the collected data was based on a questionnaire survey distributed to top management, employees and customers of MCS located in the Kingdom of Bahrain. Data collected from respondents would help MCS to implement QMS and provide the company with concrete methods to facilitate its mission in implementing QMS. The descriptive research is usually the most effective way to incorporate the accumulation of facts, data and figures. Although this has not been the sole basis for analyzing the actual data within the company. An interpretative and explanatory technique was used to process or analyze the raw data that led to consolidating information and eventually arrive at conclusions and recommendations. A questionnaire was distributed to the respondents .

The respondents fell into two groups that were top management and employees. The total average sampling was 156. The random technique implemented to select top management and employees. The sample size is computed using the Slovin's formula. Primary data was collected through a questionnaire survey that distributed to top management and employees of MCS include many questions about the advantages of QMS and its important role in every company. The respondents were so helpful and provided the researcher with their perceptions and personal points of view about implementing QMS.

The analysis of data collected used SPSS to have an accurate number of respondents result. The questionnaire was divided into 3 parts. The first part is demographic part includes information about the respondent's gender, age, position... etc. The second and last part includes (YES - NO) questions and (1= strongly disagree, 2=disagree, 3= Moderately Agree, 4= Agree and 5= Strongly Agree) type of question, which helped to determine the opinions of the respondents about implementing QMS. The questions were about implementing QMS in MCS and how it can be useful for the organization (evaluated for variables that are: General cleaning, Provision of labor services, Labor productivity, Performance, Employee behavior, Operational Costs/Expense).

\section{RESULTS AND DISCUSSION}

\section{On awareness about QMS}

Since most respondents have heard about QMS. Error! Reference source not found. 4.5 presents the background level about QMS to discover the knowledge level of employees about QMS. 25\% answered that they are beginner where they were 39, while 35.25\% said that they have average background about QMS where the number of respondents were 55 , however $26.28 \%$ stated that their background level is above average representing 41 respondents. 
Finally, $13.46 \%$ of the respondents considered themselves as experts representing 21 participants. Therefore, this determines that the majority of respondents have average background level of QMS.

2. On Respondents' background level on QMS

The results revealed that $99.36 \%$ responded with (yes) comprising 155 respondents, compared to only $0.64 \%$ (No) in which they were 1. It shows how the QMS is extremely important to the organization.

\section{On necessity of QMS Implementation}

The results shows the necessity of implementing QMS in MCS. 99.36\% said that MCS should implement QMS to improve the level of quality where the number of participants was 155 . However, $0.64 \%$ said MCS should not implement QMS to improve the level of quality in which the number of respondents was 1 . This finding presents how it is so necessary for MCS to implement QMS.

4. On the impact of implementing QMS on the internal process of MCS

The results show the respondent's opinion in the impact of implementing QMS on the internal process of MCS. The highest mean was for the statement "QMS helps use the available resources more effectively" with score of 4.23 (Agree). Followed by the statement "QMS facilitates to achieve goals" with score of 4.21 (Agree). The third highest mean was for the statement "QMS is an important factor to continuous improvement process" with score of 4.18 (Agree). Finally, the lowest mean was for statement "Using QMS beneficial is for the organization" with score of 4.16 (Agree). The overall average mean is 4.19 that is (Agree) as well.

\section{Level of efficiencies of the internal process in terms of the following:}

\subsection{General Cleaning}

The results show the respondents' opinions in the general cleaning statements. The highest mean was for the statement "QMS facilitates the process of general cleaning services" with score of 4.37 (Agree). Followed by the statement "QMS results to maintaining a good level of general cleaning service quality" with score of 4.33 (agree). The third highest mean was for the statement "QMS helps MCS to improve the cleaning services that it provides" with score of 4.32 (Agree). Finally, the lowest mean was for statement "QMS helps to provide variety of general cleaning service" with score of 4.30 (Agree). The overall average mean is 4.33 that is (Agree) as well.

\section{2 Provision of Labor Services}

Results show the respondent's opinion in the Provision of labor services statements. The highest mean was for the statement "QMS helps to perform labor performance appraisal more effectively" with score of 4.34 (Agree). Followed by the statement "QMS helps MCS to improve the Provision of labor services that it provides" with score of 4.29 (agree). The third highest mean was for the statement "QMS results to maintaining a good level of labor service quality" with score of 4.28 (Agree). Finally, the lowest mean was for statement "QMS helps to differentiate the type of labor service that they provide" with score of 4.25 (Agree). The overall average mean is 4.29 that is (Agree) as well.

\subsection{Labor Productivity}

Result shows the respondent's opinion in the Labor Productivity statements. The highest mean was for the statement "QMS helps employees to improve their productivity" with score of 4.41 (Agree). Followed by the statement "QMS helps workers determine their responsibilities and tasks to perform" with score of 4.38 (agree). The third highest mean was for the statement "QMS help employees to be more efficient in performing their tasks" with score of 4.37 (Agree). Finally, the lowest mean was for statement "QMS help to make employees more committed to their tasks" with score of 4.37 (Agree). The overall average mean is 4.33 that is (Agree) as well.

\subsection{Performance}

Result shows the respondent's opinion in the Performance statements. The highest mean was for the statement "QMS helps to reduce time to accomplish tasks" with score of 4.42 (Agree). Followed by the statement "Are the companies that use QMS more efficient and effective than the once that do not use it" with score of 4.39 (Agree). The third highest mean was for the statement "QMS helps the organization to evaluate and monitor the organization's performance" with score of 4.37 (Agree). Finally, the lowest mean was for statement "using QMS provide more control to managers on monitoring the organization's performance" with score of 4.36 (Agree). The overall average mean is 4.38 that is (Agree) as well.

\section{6 Employee Behavior}

Result shows the respondent's opinion in the Employee Behavior statements. The highest mean was for the statement "QMS helps to improve employee's performance" with score of 4.44 (Agree). Followed by the statement "QMS 


\author{
Vol. 6, Issue 5, May 2019
}

develops teamwork and result to positive work behavior" with score of 4.42 (agree). The third highest mean was for the statement "QMS helps employees to be more punctual and committed in term of attendance"with score of 4.37 (Agree). Finally, the lowest mean was for statement "QMS provides an ethical environment for employees" with score of 4.40 (Agree). The overall average mean is 4.40 that is (Agree) as well

\title{
5. 7 Operational Costs/Expenses
}

Result Error! Reference source not found.shows the respondent's opinion in the Operational Costs/Expenses statements. The highest mean was for the statement "QMS reduces the additional cost of inadequate organization" with score of 4.41 (Agree). Followed by the statement "QMS reduce the maintenance cost to organization" with score of 4.39 (Agree). The third highest mean was for the statement "QMS reduces long term cost of the organization" with score of 4.36 (Agree). Finally, the lowest mean was for statement "Implementing QMS result to reduce operational cost expenses" with score of 4.30 (Agree). The overall average mean is 4.36 which is (Agree) as well.

\section{CONCLUSION}

Findings, Conclusions and Recommendations

This chapter presents the summary of findings that were taken after processing and interpreting the data, after which the conclusions are drawn and eventually, coming up with the recommendations to further improve the incentive programs and its implementation.

\section{Summary of finding}

Determine the Quality Management System's Internal Process Implementation in MCS obtained from the outcomes of the study.

1. On the impact of implementing QMS on the internal process of MCS?

The overall average mean of the impact of implementing QMS on the internal process of MCS is 4.19, which means that the respondents agreed on the importance of this element represented in the following statement" QMS helps use the available resources more effectively". The latter has the highest mean with 4.23, while the statement" using QMS is beneficial for the organization has the lowest mean among status of QMS variables with 4.16.

2. The level of efficiencies of internal processes in term of the following:

\section{A. General cleaning:}

The overall average mean of General cleaning is 4.33, which means that the respondents agreed on the importance of this element where the statement" QMS facilitates the process of general cleaning services" has the highest mean that is 4.37. While, the statement" QMS helps to provide verity of general cleaning services" has the lowest mean among status of QMS variables which is 4.30 .

B. Provision of labor:

The overall average mean of Provision of labor is 4.29, which means that the respondents agreed on the importance of this element where the statement" QMS helps to perform labor performance appraisal more effectively" has the highest mean which is 4.34. Whereas, the statement" QMS result to maintaining a good level of labor service quality" has the lowest mean among status of QMS variables that is 4.28.

C. Labor productivity:

The overall average mean of labor productivity is 4.37, which means that the respondents agreed on the importance of this element where the statement" QMS helps employees to improve their productivity" has the highest mean which is 4.41. While, the statement" QMS help to make employees more committed to their tasks" has the lowest mean among status of QMS variables which is 4.32 .

\section{Performance:}

The overall average mean of performance is 4.38, which means that the respondents agreed on the importance of this element where the statement" QMS helps to reduce time to accomplish tasks" has the highest mean which is 4.42. Whereas, the statement" using QMS provide more control to manageress on monitoring the organizations performance" has the lowest mean among status of QMS variables which is 4.36.

E. Employee behavior:

The overall average mean of employee behavior is 4.40, which means that the respondents agreed on the importance of this element where the statement" QMS helps to improve employees performance" has the highest mean which is 4.44 
while the statement" QMS provides an ethical environment for employees" has the lowest mean among status of QMS variables which is 4.37 .

F. Operational cost/ expenses:

The overall average mean of operational cost/ expenses is 4.36, which means that the respondents agreed on the importance of this element where the statement" QMS reduces the additional cost of inadequate organization" has the highest mean which is 4.41. However, the statement" implementing QMS result to reduce operational cost/ expenses" has the lowest mean among status of QMS variables that is 4.30.

5.2.1 Role of the QMS implementation to improve MCS performance:

Based on the result of the study, the correlation analysis shows a positive correlation between implementing QMS and MCS performance. The value 0.530 illustrates the correlation between the general cleaning and quality management system implementation. The value 0.445 indicates the correlation between labor productivity and quality management system implementation. The value 0.440 shows the correlation between employee behavior and quality management system implementation. The value 0.339 indicates the correlation between operational cost/expense and Quality management system implementation. The value 0.447 shows the correlation between performance and quality management system implementation. Finally, the value 0.463 illustrates the correlation between provision of labor services and quality management system implementation.

\section{Conclusion}

Depending on the results of this study that founded in chapter 4, general cleaning variable as shown in table 4.3 with overall mean 4.33 and provision of labor services as shown in table 4.4 with mean 4.29.

However, labor productivity has overall mean of 4.37 as shown in table 4.5. Furthermore, performance variable as shown in table 4.6 with overall mean of 4.38 . In addition, table 4.7 shows the overall mean of employee behavior that is 4.40. In the end, the overall mean of operational cost was 4.36 as shown in table 4.8 .

The following are therefore concluded:

1. If QMS is being implemented in MCS it will enhance the internal process and continues improvement, moreover the MCS recourses will be used more effectively. Therefore it will lead to achieve goals.

2. On the level of efficiencies of internal processes in term of the following:

A. The relationship between QMS and general cleaning is positive. Where implementing QMS helps MCS to provide better general cleaning service and build strong relationships with customer by making them loyal through maintaining good level of quality services.

B. Implementing QMS reflects positive results on providing labors. Therefore, it helps MCS to provide better services to its customer and facilitates the process of providing labors.

3. On significant relationship between QMS implementation and the following:

A. Using QMS will help the employees of MCS to determine their responsibilities which leads to improve their productivity and the organization overall productivity.

B. When MCS uses QMS, it will facilitate the process of evaluating and monitoring the work procedure for the managers that will lead to reduce the time of performing tasks.

C. Implementing QMS helps MCS to have more control on the costs and expenses and increasing the profit which is the main objective of any profitable organization.

D. Through implementing QMS the employee behavior will be improved by providing an ethical environment and will improve the overall company performance especially the employee commitment to the work will be developed.

\section{Recommendation}

The study results have suggested that QMS has a better output to improve Performance at Mexico Cleaning Services. From the study results, the recommendations will be:

1. It is recommended that MCS better to implement QMS to enhance the internal process and facilitate achieving goals. 


\title{
International Advanced Research Journal in Science, Engineering and Technology
}

\author{
Vol. 6, Issue 5, May 2019
}

2. It is recommended that MCS better to implement QMS in order to help the organization to deliver high level of Quality for the services to the customer and that will lead to satisfy customers and make them loyal to the organization.

3. significant relationship between QMS implementation and the following:

A. It is recommended that MCS better to train its employees on how to deal with the role of QMS in order to improve their productivity.

B. It is recommended that MCS needs to implement QMS since it is a key to the attainment of organization's objectives.

C. Through implementing QMS, Mexico cleaning services should enhance the employees' performance In terms of employees' commitment to the work.

D. It is recommended that MCS it is better to implement QMS to focus more on the employees' behavior factor.

E. It is recommended that QMS it is better to implement QMS because it will help to use the resources more effectively and that will lead to reduces operational cost/ expenses.

\section{REFERENCES}

[1]. Abdulla, D. (2017). Assessing the Impact of TQM Factors on Employee Satisfaction in Health Centers in the Kingdom of Bahrain. Assessing the Impact of TQM Factors on Employee Satisfaction in Health Centers in the Kingdom of Bahrain (July 10, 2017).

[2]. Abd-Elwahed \& El-Baz, (2018), IMPACT OF IMPLEMENTATION OF TOTAL QUALITY MANAGEMENT: AN ASSESSMENT OF THE SAUDI INDUSTRY, May 2018 Vol 29(1), pp 97-107.

[3]. Azhimuratova, A. S., Tulekbayeva, A. K., Sabyrhanov, D. S., Shakkaliev, A. A., \&Meshcheryakova, E. V. (2016). The Model of Organizational Development and People Management Based on the Concept and Principles of the. International Electronic Journal of Mathematics Education, 11(7), 2087-2098.

[4]. Al-Khadher, A. M. K. M. (2015). A Study of the Implementation of Quality Management Systems (QMS) Within the Kuwaiti Manufacturing Industry (Doctoral dissertation, University of Portsmouth).

[5]. Al-Otaibi, F. M. S. (2015). Role of exploratory factor analysis applicability of TQM practices on the items of quality culture in the kingdom of Saudi Arabia. International Journal of Business and Management, 10(1), 136.

[6]. Al Khamisi, Y. N., Khan, M. K., \&Munive-Hernandez, J. E. (2018). Assessing quality management system at a tertiary hospital in Oman using a hybrid knowledge-based system. International Journal of Engineering Business Management, 10, 1847979018797006.

[7]. Astashkina, E., Momot, R., \&Salikhov, M. (2018). Impact of Workforce Flexibility on Customer Satisfaction: Empirical Framework \& Evidence from a Cleaning Services Platform.

[8]. Atamamen, F. O., Mohammed, A. H., \& Joachim, O. I. (2017). Application of Resource Based Theory to Green Cleaning Services Implementation. Advanced Science Letters, 23(9), 8373-8379.

[9]. Astashkina, E., Momot, R., \&Salikhov, M. (2018). Impact of Workforce Flexibility on Customer Satisfaction: Empirical Framework \& Evidence from a Cleaning Services Platform. Available at SSRN.

[10]. Bounabri, N., El Oumri, A. A., Saad, E., Zerrouk, L., \&Ibnlfassi, A. (2018). Barriers to ISO 9001 implementation in Moroccan organizations: Empirical study. Journal of Industrial Engineering and Management (JIEM), 11(1), 34-56.

[11]. BohrerBerni, L., Colomé Beck, C. L., CassolPrestes, F., Marion da Silva, R., Bublitz, S., \& Lamb, F. (2016). Indicators of pleasure/pain in hygiene and cleaning outsourced workers of a university hospital. Revista da Rede de Enfermagem do Nordeste, 17(2).

[12]. Blum, J. K. (2017). A Clean Break: FuerzaLaboral's Quest to Incubate a Cleaning Cooperative in Rhode Island (Doctoral dissertation, Tufts University).

[13]. Business Gateaway (2019). Cleaning Services. Retrieved from ISSA Report (2019). Cleaning Industry: Facts, Figures and Information.

[14]. Bakotić, D., \& Rogošić, A. (2017). Employee involvement as a key determinant of core quality management practices. Total Quality Management \& Business Excellence, 28(11-12), 1209-1226.

[15]. Connolly, H., Marino, S., \& Martinez Lucio, M. (2017). 'Justice for Janitors' goes Dutch: the limits and possibilities of unions' adoption of organizing in a context of regulated social partnership. Work, employment and society, 31(2), 319-335.

[16]. Dupendant, J. (2016). The Case of the International Organization for Standardization (ISO). International Regulatory Co-operation , 3-66.

[17]. Dulaimi, M., \&Ellahham, S. (2016). Using Lean management to leverage innovation in healthcare projects: case study of a public hospital in the UAE. BMJ Innovations, 2(1), 22-32.

[18]. Elkomy, S., Cookson, G., \& Jones, S. (2019). Cheap and Dirty: The Effect of Contracting Out Cleaning on Efficiency and Effectiveness. Public Administration Review, 79(2), 193

[19]. El-Morsy, A.-W., Shafeek, H., Alshehri, A. A., \& A. Gutub, S. (2014). Implementing QMS at FER as an Emerging Faculty. Implementation of Quality Management System by Utilizing ISO 9001:2008 Model in the Emerging Faculty, 967.

[20]. El-Morsy, A.-W., Shafeek, H., Alshehri, A. A., \& A. Gutub, S. (2014). Implementing QMS at FER as an Emerging Faculty. Implementation of Quality Management System by Utilizing ISO 9001:2008 Model in the Emerging Faculty, 123.

[21]. Fonseca, L. (2015). ISO 9001 Quality Management Systems through the lens of Organizational Culture. Quality - Access to Success , 16.

[22]. Glogovac, M., \& Filipovic, J. (2018). Quality costs in practice and an analysis of the factors affecting quality cost management. Total Quality Management \& Business Excellence, 29(13-14), 1521-1544.

[23]. Gustafsson, I. (2016). QUALITY MANAGEMENT SYSTEM AS AN ASSET. Business Management and Entrepreneurship , 1-49.

[24]. Hussain, S. (2016). Outsourcing Housekeeping: An insight into two cleaning companies, SOL and N-Clean, in Helsinki, Finland.

[25]. Hellemans, C., \&Lapthorn, B. (2016). Antecedents of work ability in the cleaning sector. Health Management, 9(3), 1-14.

[26]. Harris, E., \&Hongdiyanto, C. (2016). The design of standard operating procedure in cleaning service residential. JurnalKewirausahaandan Usaha Kecil Menengah, 1(1).

[27]. Ivanova, N., \& Lavrova, Z. (2017). Quality management technology impact on small enterprise production activities. In SHS Web of Conferences (Vol. 35, p. 01077). EDP Sciences.

[28]. Ingason, H. T. (2015). Best project management practices in the implementation of an ISO 9001 quality management system. Procedia-Social and Behavioral Sciences, 194, 192-200.

[29]. IBIS World Report (December, $2018 \mathrm{c}$ ). Residential Cleaning Service Franchises Industry in the US.

[30]. Ingason, H. T. (2014). Best Project Management Practices in the Implementation of an ISO 9001 Quality Management System. Best Project Management Practices in the Implementation of an ISO 9001 Quality Management System , 192-193. 


\author{
Vol. 6, Issue 5, May 2019
}

[31]. IBIS World Report (March, 2019 a). Commercial Cleaning Services- Australia Market.

[32]. IBIS World Report (March, 2019 b). Commercial Cleaning Services- New Zealand Market.

[33]. IBIS World Report (December, 2018 a). Janitorial Services Industry in the US. Retrieved

[34]. IBIS World Report (July, 2018 b). Janitorial Services - Canada Market Research Report

[35]. IBIS World Report (March, 2019 a). Commercial Cleaning Services- Australia Market. Retrieved

[36]. IBIS World Report (March, 2019 b). Commercial Cleaning Services- New Zealand Market. Retrieved

[37]. Kharub, M. (2019). Critical factors of effective implementation of IT-enabled ISO-9000 QMS. International Journal of Quality \& Reliability Management.

[38]. Kasiri, L. A., Cheng, K. T. G., Sambasivan, M., \&Sidin, S. M. (2017). Integration of standardization and customization: Impact on service quality, customer satisfaction, and loyalty. Journal of Retailing and Consumer Services, 35, 91-97.

[39]. Klungseth, N. J. (2015). Cleaning services in local

[40]. Klungseth, N. J., \&Blakstad, S. H. (2016). Organising in-house cleaning services in public FM. Facilities, 34(13/14), 828-854.

[41]. Kibe, E. N., \& Wanjau, D. (2014). The Effect of Quality Management Systems on the Performance of Food Processing Firms in Kenya. IOSR Journal of Business and Management , 16 (5), 61-72.

[42]. Karfopoulos, E., Tena, L., Torres, A., Salas, P., Jorda, J. G., Dimeas, A., \&Hatziargyriou, N. (2015). A multi-agent system providing demand response services from residential consumers. Electric Power Systems Research, 120, 163-176.

[43]. Leong, T. K., Zakuan, N., Mat Saman, M. Z., Md Arif, M. S., \& Bahari, A. Z. (2014). Implementation of Quality Management System in Malaysian Construction Industry. 360-363.

[44]. Lukichev, S., \&Romanovich, M. (2016). The quality management system as a key factor for sustainable development of the construction companies. Procedia engineering, 165, 1717-1721.

[45]. Martin, A., \& Thawabieh, F. A. (2018). The Effect of ISO 9001 to Oman Higher Education Operational Performance: Buraimi University College as a Case Study. International Journal of Applied Engineering Research, 13(6), 3939-3947.

[46]. Mohamad, H. A. D., Ab Yazid, M. S., Khatibi, A., \&Azam, S. F. (2017). Measuring the mediating role of customer satisfaction between service quality and customer loyalty in UAE hotel industry. European Journal of Management and Marketing Studies.

[47]. McKinsey and Company (Global Institute). 2017. Jobs lost, jobs gained: Workforce transitions in a time of automation. New York: McKinsey and Company.

[48]. Mitchell, B. G., Farrington, A., Allen, M., Gardner, A., Hall, L., Barnett, A. G., ...\&Gericke, C. A. (2017). Variation in hospital cleaning practice and process in Australian hospitals: A structured mapping exercise. Infection, Disease \& Health, 22(4), 195-202.

[49]. Moradi, T., Jafari, M., Maleki, M. R., Naghdi, S., \& Ghiyasvand, H. (2015). Quality Management Systems Implementation Compared With Organizational Maturity in Hospital. 8.

[50]. Neyestani, B. (2016). Effectiveness of Quality Management System (QMS) on Construction Projects. 2-3.

[51]. Otawkar, P., Darde, D., Gondke, N., Rokade, M., \& Kulkarni, M. (2017). Laundry Service System [LSS](Web Application). International Journal of Scientific Research in Computer Science, Engineering and Information Technology (IJSRCSEIT), 2(2), 936-938

[52]. Ollus, N. (2016). Forced flexibility and exploitation: experiences of migrant workers in the cleaning industry. Nordic journal of working life studies, 6(1), 25-45

[53]. Othman, N., Mokhtar, S. S. M., \&Asaad, M. N. M. (2017). QUALITY MANAGEMENT SYSTEM, EMPLOYEE SATISFACTION AND EMPLOYEE PERFORMANCE IN PRIVATE HIGHER EDUCATION INSTITUTIONS: A PROPOSED FRAMEWORK. International Journal of Management Research and Reviews, 7(6), 681.

[54]. Psomas, E., \& Antony, J. (2015). The effectiveness of the ISO 9001 quality management system and its influential critical factors in Greek manufacturing companies. International Journal of Production Research, 53(7), 2089-2099.

[55]. Russell, A. (2017). Cleaning Up the Service Sector: The Justice for Janitors Campaigns in Washington, DC, and Atlanta, GA.

[56]. Ramely, A. B., \& Ahmad, Y. (2017). Attributors of Workplace Bullying: Cleaning Workforces' Perspective. Journal of Administrative Science Special Edition: Socio-Economic Issue, 14(3).

[57]. Rehacek, P. (2017). Quality costs as an instrument of verifying the effectiveness of quality management system. Calitatea, 18(161), 109-112.

[58]. Stannojevska, M., Minovski, R., Jovanovski, B., Sajfer, Z., Coćkalo, D., \&Stanisavljev, S. (2016). Employees motivation and transition of iso 9001 QMS towards TQM. Journal of Applied Engineering Science, 14(2), 260-270.

[59]. Segal, S. (2017). Working towards employee's satisfation: exploring the perceptions of cleaners on the elements of job satisfaction in the private cleaning sector (Doctoral dissertation). http://wiredspace.wits.ac.za/handle/10539/25360

[60]. Schulten, T., \& Schulze-Buschoff, K. (2015). Sector-level strategies against precarious employment in Germany: evidence from construction, commercial cleaning, hospitals and temporary agency work (No. 197). WSI-Diskussionspapier.

[61]. Sfreddo, L. S., Vieira, G. B. B., Vidor, G., \& Santos, C. H. S. (2018). ISO 9001 based quality management systems and organisational performance: a systematic literature review. Total Quality Management \& Business Excellence, 1-21.

[62]. Seppälä, R. (2015, April 21 ). Implementing a Quality Management System for an Engineering and Services Company. 1-55.

[63]. Troynikov, O., Watson, C., Jadhav, A., Nawaz, N., \&Kettlewell, R. (2016). Towards sustainable and safe apparel cleaning methods: A review. Journal of environmental management, 182, 252-264.

[64]. Tayah, M. J., \&Assaf, H. (2018). The Future of Domestic Work in the Countries of the Gulf Cooperation Council.

[65]. Van den Borre, L., \&Deboosere, P. (2018). Health risks in the cleaning industry: a Belgian census-linked mortality study (19912011). International archives of occupational and environmental health, 91(1), 13-21.

[66]. World Bank. 2018. The changing nature of work: World development report 2019 (working draft, from 26 April 2018). Washington D.C.: World Bank.

[67]. Wilson, J. P., \& Campbell, L. (2018). ISO 9001: 2015: the evolution and convergence of quality management and knowledge management for competitive advantage. Total Quality Management \& Business Excellence, 1-16.

[68]. Zahari, N., Bakar, M., Wahid, S., \& Mydin, M.(2014). Implementation of Quality Management System for Historical Building Conservation. 1. 
International Advanced Research Journal in Science, Engineering and Technology

Vol. 6, Issue 5, May 2019

TABLES

Table 1: Awareness about QMS

\begin{tabular}{|l|l|l|}
\hline & \multicolumn{3}{c}{ Have you ever heard about QMS? } \\
\hline Answer & Quantity & Percentage \\
\hline Yes & 154 & $98.72 \%$ \\
\hline No & 2 & $1.28 \%$ \\
\hline Total & 156 & $100 \%$ \\
\hline
\end{tabular}

Table 2 : Background Level of Respondents on QMS

\begin{tabular}{|l|l|l|}
\multicolumn{3}{|c|}{ What is your background level about QMS? } \\
\hline Answer & Quantity & percentage \\
\hline Beginner & 39 & $25 \%$ \\
\hline Average & 55 & $35.25 \%$ \\
\hline Above Average & 41 & $26.28 \%$ \\
\hline Expert & 21 & $13.46 \%$ \\
\hline Total & 156 & $100 \%$ \\
\hline
\end{tabular}

Table 4 : Respondents' Perception on QMS' benefits to Organization

\begin{tabular}{|l|l|l|}
\hline Do you think that implementing QMS is beneficial to the organization? \\
\hline Answer & Quantity & Percentage \\
\hline Yes & 155 & $99.36 \%$ \\
\hline No & 1 & $0.64 \%$ \\
\hline Total & 156 & $100 \%$
\end{tabular}

Table 5 : Respondents' Perception on the Necessity of Implementing QMS

\begin{tabular}{|l|l|l|}
\hline \multicolumn{2}{|c|}{ Do you think that MCS should implement QMS to improve the level of quality? } \\
\hline Answer & Quantity & Percentage \\
\hline Yes & 155 & $99.36 \%$ \\
\hline No & 1 & $0.64 \%$ \\
\hline Total & 156 & $100 \%$
\end{tabular}

Table 6 : : Respondents' Preference in Using QMS

\begin{tabular}{|c|c|c|}
\hline \multicolumn{3}{|c|}{$\begin{array}{c}\text { If you were a general manager to an organization would you } \\
\text { prefer using QMS for your organization? }\end{array}$} \\
\hline Answer & Quantity & \\
\hline Yes & 154 & $98.72 \%$ \\
\hline No & 2 & $1.28 \%$ \\
\hline Total & 156 & $100 \%$ \\
\hline
\end{tabular}

Table 7 : Impact of Implementing QMS on the Internal Process of MCS

\begin{tabular}{|l|l|l|l|}
\hline NO & Statement & Mean & Description \\
\hline 1 & Using QMS is beneficial for the organization & 4.16 & Agree \\
\hline 2 & QMS facilitates to achieve goals & 4.21 & Agree \\
\hline 3 & QMS is an important factor to continuous improvement process & 4.18 & Agree \\
\hline 4 & QMS helps use the available resources more effectively & 4.23 & Agree \\
\hline
\end{tabular}

Table 8 : : Impact of Implementing QMS on the Internal Process of MCS for General Cleaning

\begin{tabular}{|l|l|l|l|}
\hline NO & Statement & Mean & Description \\
\hline 1 & QMS helps MCS to improve the cleaning services that it provides & 4.32 & Agree \\
\hline 2 & QMS facilitates the process of general cleaning services & 4.37 & Agree \\
\hline 3 & QMS results to maintaining a good level of general cleaning service quality & 4.33 & Agree \\
\hline 4 & QMS helps to provide variety of general cleaning service & 4.30 & Agree \\
\hline
\end{tabular}




\section{International Advanced Research Journal in Science, Engineering and Technology}

Vol. 6, Issue 5, May 2019

Table 9 : Impact of Implementing QMS on the Internal Process of MCS for Provision of Labor Services

\begin{tabular}{|l|l|l|l|}
\hline NO & Statement & Mean & Description \\
\hline 1 & QMS results to maintaining a good level of labor service quality & 4.28 & Agree \\
\hline 2 & QMS helps MCS to improve the Provision of labor services that it provides & 4.29 & Agree \\
\hline 3 & QMS helps to differentiate the type of labor service that they provide & 4.25 & Agree \\
\hline 4 & QMS helps to perform labor performance appraisal more effectively & 4.34 & Agree \\
\hline
\end{tabular}

Table 10 : Impact of Implementing QMS on the Internal Process of MCS for Labor Productivity

\begin{tabular}{|l|l|l|l|l|}
\hline NO & Statement & Mean & Description \\
\hline 1 & QMS helps workers determine their responsibilities and tasks to perform & 4.38 & Agree \\
\hline 2 & QMS helps employees to improve their productivity & 4.41 & Agree \\
\hline 3 & QMS help to make employees more committed to their tasks & 4.32 & Agree \\
\hline 4 & QMS help employees to be more efficient in performing their tasks & 4.37 & Agree \\
\hline
\end{tabular}

Table 11 : Impact of Implementing QMS on the Internal Process of MCS for Performance

\begin{tabular}{|l|l|l|l|l|}
\hline 1 & $\begin{array}{l}\text { Using QMS provide more control to managers on monitoring the } \\
\text { organization's performance }\end{array}$ & 4.36 & Agree \\
\hline 2 & $\begin{array}{l}\text { Are the companies that use QMS more efficient and effective than the } \\
\text { ones that do not use it }\end{array}$ & 4.39 & Agree \\
\hline 3 & $\begin{array}{l}\text { QMS helps the organization to evaluate and monitor the organization's } \\
\text { performance }\end{array}$ & 4.37 & Agree \\
\hline 4 & $\begin{array}{l}\text { QMS helps to reduce time to accomplish tasks } \\
\text { Average Mean }\end{array}$ & 4.42 & Agree \\
\hline
\end{tabular}

Table 12 : Impact of Implementing QMS on the Internal Process of MCS for Employee Behaviour

\begin{tabular}{|l|l|l|l|}
\hline NO & Statement & Mean & Description \\
\hline 1 & QMS helps to improve employee's performance & 4.44 & Agree \\
\hline 2 & QMS develops teamwork and result to positive work behavior & 4.42 & Agree \\
\hline 3 & $\begin{array}{l}\text { QMS helps employees to be more punctual and committed in term of } \\
\text { attendance }\end{array}$ & 4.37 & Agree \\
\hline 4 & QMS provides an ethical environment for employees & 4.37 & Agree \\
\hline A verage Mean & $\mathbf{4 . 4 0}$ & Agree
\end{tabular}

Table 13 : Impact of Implementing QMS on the Internal Process of MCS for Operational Cost/Expenses

\begin{tabular}{|l|l|l|l|}
\hline NO & Statement & Mean & Description \\
\hline 1 & QMS reduces the additional cost of inadequate organization & 4.41 & Agree \\
\hline 3 & QMS reduce the maintenance cost to organization & 4.39 & Agree \\
\hline 4 & QMS reduces long term cost of the organization & 4.36 & Agree \\
\hline
\end{tabular}

